Thuyết "cái vòng luẩn quẩn" và "cú huých từ bên ngoài" của Samuelson và thực tiễn hoạt động đâu tư trực tiếp nước ngoài tại Việt Nam

Trần Văn Hùng \& Phạm Duy Linh

October 27, 2015

Tạp chí Phát triển \& Hội nhập

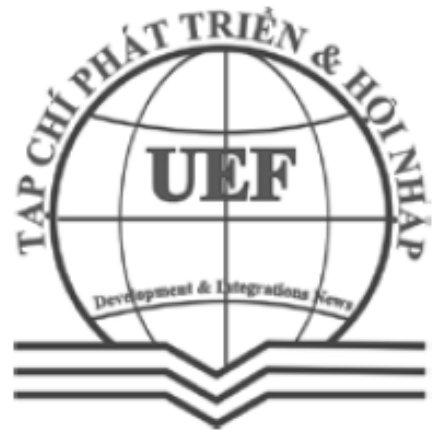

Số 24(34) - Tháng 09-10/2015 


\section{Thuyết "cái vòng luẩn quẩn" và "cú huých từ bên ngoài" của Samuelson và thực tiễn hoạt động đầu tư trực tiếp nước ngoài tại Việt Nam}

\section{TRÂN VĂN HÙNG \& PHAM DUY LINH}

Nhận bài: 30/06/2015 - Duyệt đăng: 13/08/2015

B ài viết đề cập đến học thuyết "cái vòng luẩn quẩn" và "cú huých tù bên ngoài” của Samuelson, cu thể là nọi dung của học thuyết, nhũng mặt đạt được và nhũng mặt hạn chế của hoc thuyết. Trên co' sở nguồn số liệu thư cấp thu thập được tù các co quan ban ngành, bài viết nêu việc áp dụng lý thuyết này tại VN thông qua hoạt động thu hút vốn đầu tu trụcc tiếp nước ngoài. Ngoài ra, bài viết còn nêu lên một số hạn chế của việc thu hút nguồn vốn FDI và đưa ra một số biện pháp khuyến nghi góp phần nâng cao chất lượng dòng vốn FDI ở VN.

Tù̀ khóa: Thuyết Samuelson, vốn FDI.

\section{Giới thiệu}

Nhà kinh tế học Samuelson với tác phẩm "Kinh tế học" ra đời vào năm 1948, trong đó ông đưa ra thuyết "Cái vòng luẩn quẩn" và "Cú huých từ bên ngoài”. Với lý thuyết này nhiều quốc gia đã vận dụng vào quá trình phát triển nền kinh tế nhất là đối với các nước đang phát triển như VN. Vận dụng lý thuyết này, các quốc gia muốn đạt mức tăng trưởng kinh tế thì cần có một cú huých từ bên ngoài cụ thể như yếu tố về vốn, khoa học công nghệ hiện đại, chuyên gia... trong đó thì yếu vốn đầu tư trực tiếp nước ngoài (FDI) đóng vai trò là cú huých mang tính đột phá quan trọng trong yếu tố tăng trưởng kinh tế của các quốc gia. Từ những lý do trên, thông qua việc tìm hiểu về lý thuyết "Cái vòng luẩn quẩn" và "Cú huých từ bên ngoài" của Samuelson, bài viết nêu lên những ưu điểm và nhược điểm của lý thuyết này, việc vận dụng học thuyết này vào thực tiễn hoạt động của $\mathrm{VN}$ trong thời gian vừa qua mà cụ thể là thực tiễn hoạt động thu hút vốn đầu tư nước ngoài vào $\mathrm{VN}$ nhằm làm sáng tỏ luận thuyết trên.

\section{Nội dung học thuyết Samuelson}

Lý thuyết này cũng cùng quan điểm với trường phái tân cổ điển cho rằng có 4 nhân tố ảnh hưởng và là nguồn gốc của tăng trưởng kinh tế: nguồn nhân lực, tài nguyên thiên nhiên, tư bản và kỹ thuật. Samuelson cho rằng các yếu tố này ở các nước đang phát triển đều khan hiếm nên việc kết hợp bốn yếu tố này gặp khó khăn trở ngại lớn và ở nhiều nước nghèo khó khăn lại càng tăng thêm trong "cái vòng luẩn quẩn" của sự nghèo khổ. "Vòng luẩn quẩn" nghèo khổ có thể được biểu thị qua Hình 1 .

Samuelson cũng nhấn mạnh rằng để phá vỡ vòng luẩn quẩn này thì cần phải có "Cú huých từ bên

Hình 1: Cái vòng luẩn quẩn của sụ̣ nghèo khổ

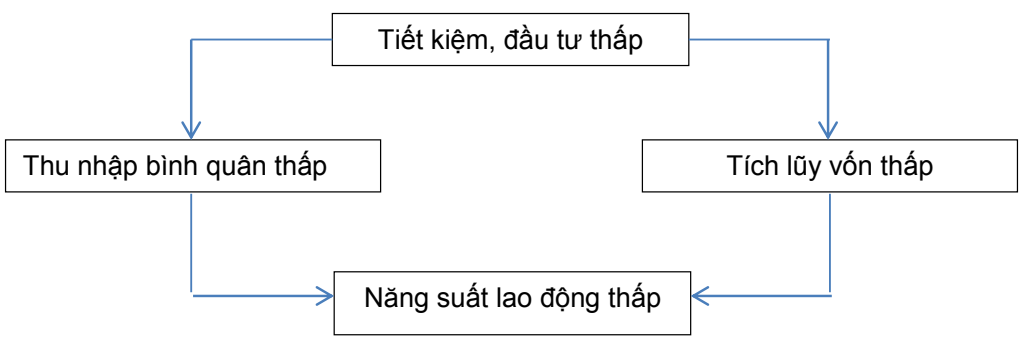


ngoài". Tức là các quốc gia này cần có sự đầu tư từ bên ngoài về về vốn, công nghệ, chuyên gia... Vì vậy, các nước đang phát triển cần phải có đầu tư nước ngoài, phải tạo điều kiện thuận lợi để kích thích đầu tư nước ngoài nhằm vực dậy và phát triển nền kinh tế.

\section{3. Đánh giá chung về những kêt quả đạt được và hạn chế của học thuyết}

\subsection{Nhũng kết quả đạt đựcc của hoc thuyết}

Học thuyết về "cái vòng luẩn quẩn" và "cú huých bên ngoài" của Samuelson đã có sự kế thừa và phát triển từ nhiều trường phái kinh tế khác nhau.

Học thuyết này đề cao mô hình kinh tế hỗn hợp và nhấn mạnh đến cơ chế thị trường tự do cạnh tranh tức là nền kinh tế cần có sự kết hợp giữa thành phần kinh tế tư nhân với kinh tế nhà nước và được điều hành bởi cơ chế thị trường nhưng có sự quản lý của nhà nước. Cơ chế thị trường giúp phát huy hiệu quả các nguồn lực cho phát triển kinh tế.

Học thuyết còn nêu lên sự cần thiết của nhà nước trong việc điều tiết vĩ mô nền kinh tế thông qua các chức năng và công cụ của mình để phát huy để phát huy mặt tích cực và khắc phục khuyết tật của cơ chế thị trường. Bởi vì cơ chế thị trường không hẳn hoàn toàn tối ưu và nó luôn tồn tại những khuyến tật như hiện tượng độc quyền, ô nhiễm môi trường, khủng hoảng, thất nghiệp, sự phân phối bất bình đẳng... Bên cạnh đó học thuyết cũng chỉ ra những hạn chế của nhà nước khi điều hành nền kinh tế như nhà nước không lựa chọn các yếu tố phù hợp cho phát triển các ngành nghề, sự tài trợ của chính phủ có lúc kém hiệu quả như chương trình đầu tư quá lớn và thời gian quá dài, bị chi phối bởi ý kiến chủ quan của một bộ phận nhỏ nhà quản lý đưa ra các quyết sách phục vụ lợi ích nhóm hoặc bởi những người bất tài, tham nhũng,...dẫn đến việc đưa ra những quyết định sai lầm, không phù hợp với quy luật khách quan, không phản ánh đúng sự vận động của thị trường. Vì vậy, Samuelson cũng đã nhấn mạnh rằng chính phủ chỉ nên can thiệp có giới hạn vào thị trường.

Đối với các nước đang phát triển, học thuyết này đã phân tích, đánh giá và nêu các nguồn lực cần thiết để phát triển kinh tế và nó chính là nền tảng cơ sở lý thuyết cho các nước vận dụng vào sự quản lý và điều tiết kinh tế của chính phủ.

Học thuyết cũng đã đề cao vai trò của đầu tư nước ngoài đối với phát triển kinh tế ở các nước đang phát triển, các nguồn vốn đầu tư từ nước ngoài đã có nhiều đóng góp cho phát triển kinh tế ở các nước đang phát triển như: bổ sung nguồn vốn cho nền kinh tê, tăng nguồn thu cho ngân sách nhà nước, giải quyết việc làm cho người lao động, tiếp thu khoa học công nghệ hiện đại, kinh nghiệm quản lý của nước ngoài, mở rộng thị trường tiêu thụ và mở cửa hội nhập nền kinh tế với thế giới v.v.

\subsection{Nhũng hạn chế của học thuyết}

Các quốc gia đang phát triển đều có các điều kiện tự nhiên và điều kiện kinh tếxã hội cũng như nguồn lực khác nhau nên không phải quốc gia nào cũng vận dụng "cú huých bên ngoài" đều phát triển nền kinh tế và thành công. Tùy điều kiện của từng quốc gia mà lựa chọn các yếu tố đầu tư từ nước ngoài cho phù hợp. Thực tiễn cũng cho thấy chỉ có một số ít quốc gia vận dụng thành công như NICs, còn lại phần lớn lợi ích thuộc về các nhà đầu tư nước ngoài. Do đó, học thuyết này không thể áp dụng rộng rãi cho tất cả các quốc gia mà mỗi quốc gia tùy vào điều kiện của mình vận dụng linh hoạt học thuyết này

Việc vận dụng không phù hợp "cú huých từ bên ngoài" và lựa chọn các yếu tố từ đầu tư nước ngoài không phù hợp đã dẫn đến nhiều hệ lụy mà các quốc gia đang phát triển phải đối mặt như sự ô nhiễm trường làm giảm tính bền vững của tăng trưởng kinh tế, sử dụng công nghệ lạc hậu, phụ thuộc vào nước ngoài chi phối, sự phát triển thiếu cân đối giữa các vùng miền, gia tăng sức ép cho các đô thị, tình trạng phân hóa giàu nghèo v.v.

\section{Thực trạng áp dụng thuyết của Samuelson trong hoạt động thu hút vốn đâu tư trực tiếp nước ngoài (FDI) vào VN}

\subsection{Quá trình hình thành đầu tư trục tiếp ngước ngoài tại $V N$ trong thòi gian qua}

Kể từ khi có Luật Đầu tư trực tiếp nước ngoài có hiệu lực năm 1988, dòng vốn FDI đã có tác động tích cực trong quá trình phát triển kinh tế xã hội của nước ta trong suốt gần 30 năm đổi mới đất nước. Khu vực kinh tế có vốn đầu tư nước ngoài (FDI) luôn phát triển năng động, ngày càng phát huy vai trò quan trọng và có những đóng góp đáng kể trong sự nghiệp phát triển kinh tế - xã hội của VN. Trong 25 năm từ 1988-2013, tổng vốn FDI đăng ký vào VN đạt khoảng 218,8 tỷ USD, tổng vốn thực hiện đạt 106,3 tỷ USD, lĩnh vực công nghiệp chiếm tới gần $60 \%$. Thông tin từ Cục Đầu tư nước ngoài - Bộ Kế hoạch và Đầu tư cho biết tính cho cả cấp mới và tăng vốn trong 
năm 2014 thì nhà đầu tư nước ngoài đã đăng ký đầu tư vào $\mathrm{VN}$ 20,2 tỷ USD, giảm $6,5 \%$ so với năm 2013 và vượt 19\% kế hoạch năm 2014 (17 tỷ USD). Các doanh nghiệp FDI đã có mặt và lấn át ở hầu hết các lĩnh vực của nền kinh tế. Thu hút vốn đầu tư FDI đã đem lại những kết quả khả quan, phù hợp với tiến trình phát triển kinh tế. Tuy nhiên bên cạnh những thành tựu đã đạt được vẫn tồn tại những hạn chế trong quá trình thu hút vốn FDI. Do đó, cần có sự đánh giá thực trạng thu hút vốn FDI, nêu những hạn chế, bất cập, những tác động tiêu cực để có hướng đề xuất biện pháp nhằm sử dụng hiệu quả nguồn vốn này.

\subsection{Thực trạng thu hút vốn đầu tư trục tiếp nước ngoài tai $V N$}

Theo Báo cáo tổng kết 26 năm đầu tư trực tiếp nước ngoài (FDI) tại VN (kể từ khi có Luật Đầu tư nước ngoài năm 1988) của Bộ Kế hoạch và Đầu tư, tính đến hết năm 2013, VN đã thu hút được 14.550 dự án có vốn đầu tư trực tiếp nước ngoài (FDI) còn hiệu lực với tổng vốn đăng ký đạt gần 211 tỷ USD, vốn thực hiện đạt gần 100 tỷ USD. Sự gia tăng mạnh mẽ của vốn đầu tư nước ngoài thực hiện được thể hiện rõ nét qua các thời kỳ. Từ khoảng 20,67 tỷ USD, chiếm $24,32 \%$ tổng vốn đầu tư xã hội giai đoạn 1991-2000 đã tăng lên 69,47 tỷ USD, chiếm 22,75\% tổng vốn đầu tư xã hội giai đoạn 2001-2011. Tỷ trọng khu vực đầu tư nước ngoài trong cơ cấu kinh tế giai đoạn 2000-2011 tăng 5,4\%. Tỷ trọng đóng góp của đầu tư trực tiếp nước ngoài vào GDP tăng dần qua các năm và đạt khoảng $19 \%$ GDP vào năm 2011, đóng góp 14,2 tỷ USD cho thu ngân sách giai đoạn 2001 - 2010. Riêng năm 2012, khu vực này đóng góp cho thu ngân sách khoảng 3,7 tỷ USD, chiếm 11,9\% tổng thu ngân sách.

Nhìn chung vốn đầu tư nước ngoài $\mathrm{FDI}$ vào $\mathrm{VN}$ tăng dần qua các năm, đầu tư nước ngoài FDI hiện là khu vực phát triển mạnh nhất trong các khu vực kinh tế. Vốn đầu tư nước ngoài chủ yếu tập trung vào sản xuất công nghiệp, tốc độ tăng trưởng của khu vực FDI ngành công nghiệp đạt bình quân gần $18 \% /$ năm, cao hơn tốc độ tăng trưởng toàn ngành. Đến nay, khu vực FDI đã tạo ra gần $45 \%$ giá trị sản xuất toàn ngành công nghiệp, đồng thời góp phần hình thành một số ngành công nghiệp chủ lực của nền kinh tế như viê̂̃n thông; thăm dò, khai thác, chế biến dầu khí; sản xuất các sản phẩm điện tử; công nghệ thông tin; sản xuất thép, xi măng ...

Thu hút đầu tư vốn FDI vào lĩnh vực công nghiệp chế biến, chế tạo là lĩnh vực thu hút được nhiều sự quan tâm của nhà đầu tư nước ngoài với 774 dự án đầu
Bảng 1: Tình hình thu hút vốn đầu tư trực tiếp nước ngoài giai đoạn 2000 - 2014

\begin{tabular}{cccc}
\hline Năm & $\begin{array}{c}\text { Số dự } \\
\text { án } \\
\text { được } \\
\text { cấp } \\
\text { phép }\end{array}$ & $\begin{array}{c}\text { Vốn } \\
\text { đăng ký } \\
\text { (triệu } \\
\text { USD) }\end{array}$ & $\begin{array}{c}\text { Vốn } \\
\text { thực hiện } \\
\text { (triệu } \\
\text { USD) }\end{array}$ \\
\hline 2000 & 391 & $2.838,9$ & $2.413,5$ \\
2001 & 555 & $3.142,8$ & $2.450,5$ \\
2002 & 808 & $2.998,8$ & $2.591,0$ \\
2003 & 791 & $3.191,2$ & $2.650,5$ \\
2004 & 811 & $4.547,6$ & $2.852,5$ \\
2005 & 970 & $6.839,8$ & $3.308,8$ \\
2006 & 833 & $12.004,0$ & $4.100,1$ \\
2007 & 1.544 & $20.347,8$ & $8.030,0$ \\
2008 & 1.557 & $60.217,0$ & $11.500,0$ \\
2009 & 839 & $21.482,0$ & $10.000,0$ \\
2010 & 1.155 & $18.595,0$ & $11.000,0$ \\
2011 & 1.198 & $14.700,0$ & $11.000,0$ \\
2012 & 1.287 & $13.013,0$ & $10.460,0$ \\
2013 & 1.275 & $21.628,0$ & $11.500,0$ \\
2014 & 1.588 & $20.230,9$ & $12.350,0$ \\
\hline & & &
\end{tabular}

Nguồn: Tổng cục Thống kê, Bộ Kế hoạch và đầu tư

tư đăng ký mới, tổng số vốn cấp mới và tăng thêm là 14,49 tỷ USD, chiếm $72 \%$ tổng vốn đầu tư đăng ký. Lĩnh vực kinh doanh

Bảng 2: Tình hình thu hút vốn FDI năm 2014: Phân theo lính vực và vùng kinh tế

\begin{tabular}{|c|c|c|c|}
\hline I. Phân theo lĩnh vực & $\begin{array}{c}\text { Số } \\
\text { dự án }\end{array}$ & $\begin{array}{c}\text { Số vốn } \\
\text { (tỷ USD) }\end{array}$ & Tỷ trọng $(\%)$ \\
\hline 1.Công nghiệp chế biến, chế tạo & 774 & 14,49 & 71,63 \\
\hline 2. Kinh doanh bất động sản & 35 & 2,54 & 12,56 \\
\hline 3. Xây dựng & 3 & 1,05 & 5,19 \\
\hline 4. Khác & 776 & 2,15 & 10,63 \\
\hline Tổng cộng & 1.588 & 20,23 & 100,00 \\
\hline II. Theo vùng kinh tế & Số DA & $\begin{array}{l}\text { Số vốn (tỷ } \\
\text { USD) }\end{array}$ & Tỷ trọng $(\%)$ \\
\hline 1. Khu vực Đông Nam Bộ & & 7,2 & 35,59 \\
\hline 2. Đồng bằng sông Hồng & & 6,2 & 30,65 \\
\hline 3. Bắc Trung Bộ và Duyên hải miền Trung & & 2,1 & 10,38 \\
\hline $\begin{array}{l}\text { 4. Khu vực Đồng bằng sông Cửu Long, } \\
\text { Tây Nguyên, Trung du và miền núi phía } \\
\text { Bắc và vùng khác }\end{array}$ & & 4,73 & 23,38 \\
\hline Tổng cộng & & 20,23 & 100,00 \\
\hline
\end{tabular}

Nguồn: Tổng cục Thống kê, Bộ Kế hoạch và Đầu tư 
bất động sản đứng thứ 2 với 35 dự án đầu tư đăng ký mới, tổng vốn đầu tư cấp mới và tăng thêm là 2,54 tỷ USD, chiếm 12,6\% tổng vốn đầu tư đăng ký. Đứng thứ 3 là lĩnh vực xây dựng với tổng số vốn đăng ký cấp mới và tăng thêm là 1,05 tỷ USD, chiếm $5,2 \%$ tổng vốn đăng ký.

Có thể thấy tỷ trọng ngành công nghiệp chế biến chế tạo trong tổng vốn đăng ký của cả nước đã tăng đều trong thời gian vừa qua (năm 2011 chiếm $50 \%$, năm 2012: 70\%, năm 2013: 76,6\%, năm 2014: 72\%). Trong đó, đã xuất hiện nhiều dự án có hàm lượng công nghệ cao, đóng góp vào phần chuyển dịch cơ cấu ngành và chuyển giao công nghệ, kỹ thuật sản xuất. Định hướng đầu tư này là phù hợp với mục tiêu và định hướng thu hút ĐTNN theo ngành và lĩnh vực của VN.

Vốn FDI đầu tư vào công nghiệp chủ yếu là công nghiệp dầu khí, công nghiệp nhẹ, công nghiệp nặng, công nghiệp thực phẩm, xây dựng và được định hướng theo hướng sản xuất vật liệu mới, sản phẩm công nghệ cao, công nghệ thông tin, cơ khí chế tạo, thiết bị cơ khí chính xác, sản phẩm linh kiện điện tử. Đây cũng chính là khu vực có khả năng tạo ra giá trị cao và $\mathrm{VN}$ có lợi thế khi thu hút vốn đầu tư nước ngoài.

Ngành dịch vụ cũng thu hút lượng lớn vốn FDI đầu tư, trong đó chủ yếu đầu tư vào lĩnh vực giao thông vận tải, bưu điện, logistic, khách sạn, nhà hàng, văn phòng cho thuê, khu đô thị mới, tài chính ngân hàng, các dịch vụ nghiên cứu thị trường, trợ giúp pháp lý...
Chủ trương khuyến khích khu vực FDI hướng về xuất khẩu đã tạo thuận lợi cho VN trong việc nâng cao năng lực xuất khẩu, qua đó $\mathrm{VN}$ từng bước tham gia và cải thiện vị trí trong chuỗi giá trị toàn cầu. Không những thế khu vực FDI góp phần làm thay đổi cơ cấu mặt hàng xuất khẩu theo hướng giảm tỷ trọng xuất khẩu sản phẩm khai khoáng, mặt hàng sơ cấp, tăng dần tỷ trọng hàng xuất khẩu của công nghiệp chế biến, chế tạo. FDI tác động tích cực tới việc mở rộng thị trường xuất khẩu sang các nước châu Âu, đặc biệt là thị trường xuất khẩu sang Mỹ - nơi mà hàng hóa nhập khẩu được kiểm định rất nghiêm ngặt. Đến nay, Mỹ đã trở thành một trong những thị trường xuất khẩu lớn nhất của $\mathrm{VN}$. Điều đó chứng tỏ một số mặt hàng của $\mathrm{VN}$ sản xuất đã đạt đến tiêu chuẩn cao, đáp ứng được yêu cầu của nhập khẩu vào thị trường Mỹ. Ngoài ra, các doanh nghiệp FDI còn góp phần ổn định thị trường trong nước, hạn chế nhập siêu thông qua việc cung cấp cho thị trường nội địa các sản phẩm chất lượng cao do doanh nghiệp trong nước sản xuất.

Thu hút đầu tư vốn FDI theo vùng kinh tế: Khu vực Đông Nam Bộ (gồm 6 tỉnh/thành phố: TP.HCM, Bà Rịa- Vũng Tàu, Bình Dương, Đồng Nai, Bình Phước, Tây Ninh) hiện dẫn đầu cả nước về thu hút vốn FDI với 7,2 tỷ USD tổng vốn đầu, chiếm $35,7 \%$ tổng số vốn đầu tư của cả nước tư trong năm 2014. Đứng thứ hai là khu vực Đồng bằng sông Hồng với 6,2 tỷ USD tổng vốn đầu tư, chiếm $31 \%$ tổng vốn đầu tư của cả nước. Đây là 2 vùng kinh tế lớn nhất của cả nước, có cơ sở hạ tầng tốt, lực lượng lao động dồi dào, có tay nghề và thu hút nhiều dự án ĐTNN. Đứng thứ ba là khu vực Bắc Trung Bộ và Duyên hải miền Trung với 2,1 tỷ USD vốn đầu tư, chiếm 10,7\% tổng vốn đầu tư của cả nước. Khu vực Đồng bằng sông Cửu Long, Tây Nguyên, Trung du và miền núi phía Bắc có kết quả thu hút ĐTNN còn hạn chế do đây là những khu vực có điều kiện cơ sở hạ tầng yếu kém, xa các trung tâm kinh tế của cả nước.

\subsection{Tác động tích cục, tác động tiêu cục và một số hạn chế của nguồn vốn FDI đối với nền kinh tế $V N$}

4.3.1. Tác động tích cực của nguồn vốn FDI đối với nền kinh tế $V N$

Là nguồn vốn hỗ trợ cho phát triển kinh tế nhằm mục tiêu xây dựng VN trở thành một nước công nghiệp về cơ bản và phát triển kinh tế $\mathrm{VN}$ theo cơ chế kinh tế thị trường định hướng xã hội chủ nghĩa, nguồn vốn FDI chính là nguồn vốn quan trọng hỗ trợ cho phát triển kinh tế tại VN. Đóng góp của FDI qua các giai đoạn đều chiếm khoảng 16\% tổng vốn đầu tư xã hội trong giai đoạn giai đoạn 2001-2006, giai đoạn 2007-2013, với sự gia tăng đáng kể về vốn giải ngân, có sự cải thiện về đóng góp. Cụ thể từ năm 2007 cho đến 2013, vốn FDI luôn chiếm tỷ trọng từ 21$30 \%$ trong tổng vốn đầu tư phát triển xã hội.

Lãi suất cố định: FDI có nhiều ưu thế hơn so với các hình thức huy động khác; ví dụ việc vay vốn nước ngoài luôn đi cùng với một mức và đôi khi trở thành gánh nặng cho nền kinh tế hoặc là các khoản viện trợ thường đi 
kèm với điều kiện về chính trị.

Nguồn vốn FDI vào $\mathrm{VN}$ đồng thời sẽ tạo ra các tác động tích cực đối với việc huy động các nguồn vốn khác như ODA, NGO, đồng thời kích thích thu hút vốn đầu tư trong nước.

Chuyển giao công nghệ: Với mục tiêu công nghiệp hóa, hiện đại hóa đất nước theo định hướng XHCN, khoảng cách phát triển khoa học công nghệ giữa các nước phát triển, nhất là $\mathrm{VN}$ với các nước công nghiệp phát triển còn lớn. Việc các nước đang phát triển tự nghiên cứu để phát triển khoa học kỹ thuật cho kịp với trình độ của các nước phát triển là việc khó khăn và tốn kém. Đây là cơ hội cho các nước đang phát triển, trong đó có $\mathrm{VN}$ để có thể tiếp thu được kỹ thuật-công nghệ thuận lợi nhất, tạo điều kiện thuận lợi để rút ngắn con đường phát triển của mình.

Thúc đẩy quá trình dịch chuyển cơ cấu kinh tế: Thông qua đầu tư trực tiếp nước ngoài, nhiều lĩnh vực và ngành kinh tế mới ở nước nhận đầu tư đã xuất hiện như dầu khí, công nghệ thông tin, hóa chất, ô tô, xe máy, thép, điện tử và điện tử gia dụng, công nghiệp chế biến nông sản thực phẩm, da giày, dệt may... FDI giúp nhanh chóng thúc đẩy trình độ kỹ thuật - công nghệ ở nhiều ngành kinh tế, góp phần tăng năng suất lao động ở các ngành này và làm tăng tỷ trọng của nó trong nền kinh tế.

Hoạt động thu hút FDI đã góp phần mở rộng quan hệ kinh tế đối ngoại, tạo thuận lợi để VN gia nhập ASEAN, ký Hiệp định khung với EU, Hiệp định thương mại với Mỹ, Hiệp định khuyến khích và bảo hộ đầu tư với 62 quốc gia/vùng lãnh thổ và Hiệp định đối tác kinh tế (EPA) với Nhật và nhiều quốc gia; đưa $\mathrm{VN}$ từng bước tham gia chuỗi giá trị sản xuất toàn cầu.

4.3.2. Tác động tiêu cưc của nguồn vốn FDI đối với nền kinh tế $V N$

Mặc dù có nhiều tác động tích cực tới kinh tế và sự phát triển bền vững của đất nước, vốn FDI cũng có những tác động tiêu cực trên nhiều lĩnh vực, cụ thể:

Vốn FDI tạo cơ hội để một nguồn vốn lớn chảy ra bên ngoài (lợi nhuận, các khoản thanh toán khác, v.v. của các nhà đầu tư nước ngoài tại $\mathrm{VN}$ ), ảnh hưởng đến lượng ngoại hối của nước nhận đầu tư, giảm đóng góp vào nguồn thu thuế của VN. Đầu tư nước ngoài đôi khi biệt lập với các ngành sản xuất trong nước, do đó không có những hiệu ứng lan truyền có lợi về mặt phổ biến công nghệ sản xuất, quản lý và marketing. Tiếp nhận FDI nhất là của các công ty đa quốc gia, xuyên quốc gia có thể làm cho các nhà sản xuất trong nước đứng trước một cuộc cạnh tranh mới với đối thủ có tiềm lực mạnh và không cân sức.

Đối với môi trường: Việc chuyển giao công nghệ của các dự án FDI cũng có mặt hạn chế. Đó là bất kỳ một tổ chức nào muốn thay thế kỹ thuật-công nghệ mới thì phải tìm được nơi loại bỏ những kỹ thuật-công nghệ cũ. Việc loại bỏ các công nghệ cũ này dễ dàng được nhiều nơi chấp nhận nên các nước phát triển xem các nước đang phát triển như nơi tiếp nhận các máy móc lạc hậu. Bởi vậy, các nước đang phát triển có thể dễ dàng bị biến thành "bãi rác"công nghiệp.
Trong tổng các dự án FDI đăng ký, nhiều dự án đầu tư vào các ngành khai thác tài nguyên, tận dụng bảo hộ, công nghiệp gây ô nhiễm và bất động sản và điều này không có tác dụng lan tỏa. Vốn đầu tư vào các ngành bảo hộ thì không có sức cạnh tranh chỉ làm cho chi phí của nền kinh tế gia tăng; vốn đầu tư vào các ngành công nghiệp gây ô nhiễm thì lợi nhuận họ hưởng, còn hậu quả và chi phí khắc phục thì ta chịu; vốn đầu tư vào bất động sản thì có thể làm căng thêm "bong bóng", dễ gây ra bất ổn.

Công nghệ được sử dụng thường cao hơn mặt bằng công nghệ cùng ngành và cùng loại sản phẩm của khu vực kinh tế trong nước, nhưng do phần lớn là từ các nước châu Á (69\%, Đông Nam Á chiếm 19\%), các nước châu Âu mới chiếm $24 \%$, châu Mỹ chiếm 5\%, các nước G8 mới chiếm $23,7 \%$ nên chưa thu hút được nhiều đầu tư từ các nước công nghiệp phát triển, công nghệ nguồn. Có một số trường hợp, nhà đầu tư nước ngoài đã lợi dụng sơ hở của pháp luật VN, cũng như sự yếu kém trong việc kiểm tra, giám sát tại các cửa khẩu, nên đã nhập vào $\mathrm{VN}$ một số máy móc, thiết bị có công nghệ lạc hậu.

4.3.3. Một số hạn chế trong quá trình thu hút vốn đầu tu trục tiếp nuoớc ngoài ở $V N$

Bên cạnh những kết quả đạt được, khu vực FDI còn có những hạn chế, tồn tại như hiệu quả tổng thể nguồn vốn đầu tư nước ngoài chưa cao, giá trị gia tăng tạo ra tại VN và khả năng tham gia chuỗi giá trị thấp, định hướng thu hút đầu tư nước ngoài theo ngành, đối tác còn hạn chế; mục tiêu thu 
hút công nghệ, chuyển giao công nghệ chưa đạt yêu cầu; hiệu ứng lan tỏa của khu vực đầu tư nước ngoài sang khu vực khác của nền kinh tế còn hạn chế; một số dự án chất lượng chưa cao, quy mô dự án nhỏ, tỷ lệ giải ngân thấp so với yêu cầu...Cụ thể, đầu tư nước ngoài thời gian qua hướng vào những ngành thâm dụng lao động, sử dụng tài nguyên, tận dụng chính sách bảo hộ công nghiệp trong khi các ngành sử dụng công nghệ cao, tạo ra nhiều giá trị gia tăng chưa nhiều.

Đầu tư của các nước phát triển vào $\mathrm{VN}$ còn hạn chế nếu so với đầu tư của các nước này vào Thái Lan, Indonesia, Malaysia. Cho đến nay, mới chỉ có trên 100 trong tổng số 500 tập đoàn xuyên quốc gia có mặt tại $\mathrm{VN}$, thấp hơn nhiều con số 400 tập đoàn ở thị trường Trung Quốc.

Tỷ lệ vốn thực hiện thấp so với vốn đăng ký, chỉ khoảng 47,2\%. Hầu hết các dự án FDI vào $\mathrm{VN}$ có quy mô nhỏ và vừa, trung bình cả giai đoạn 1988 - 2011 chỉ ở mức 15,4 triệu USD/dự án; năm 2013 trung bình 13,47 triệu USD/dự án và năm 2014 giảm xuống còn trung bình 9,8 triệu USD/dự án.

Trên $80 \%$ doanh nghiệp FDI sử dụng công nghệ trung bình của thế giới, chỉ có $5-6 \%$ là sử dụng công nghệ cao và $14 \%$ ở mức thấp, lạc hậu.

Tỷ lệ dự án FDI giải thể trước thời hạn, dự án xin giãn tiến độ, các dự án chậm triển khai, các dự án có nhà đầu tư bỏ trốn (khoảng 1.000 doanh nghiệp) tương đối cao.

Tỷ lệ việc làm mới do khu vực FDI tạo ra không tương xứng, chỉ chiếm 3,4\% tổng số lao động có việc làm năm 2011.
Thu nhập bình quân của người lao động mặc dù được đánh giá cao hơn khu vực doanh nghiệp tư nhân trong nước song lại thấp hơn khu vực doanh nghiệp nhà nước. Nhu cầu về nhà ở, đời sống văn hóa ở các khu tập trung nhiều lao động đã trở nên bức xúc mà chưa đáp ứng được.. Những hạn chế này dẫn đến từ năm 1995 đến nay cả nước xảy ra 4.142 cuộc đình công, trong đó $75 \%$ của doanh nghiệp FDI, chủ yếu từ các doanh nghiệp của Đài Loan, Hàn Quốc, Trung Quốc, Nhật chủ yếu là vấn đề thỏa mãn mức tiền lương và điều kiện lao động.

Ngoài ra, một số doanh nghiệp tạo nên tình trạng lỗ giả, lãi giả, gây thất thu ngân sách, làm cho đa số bên VN phải rút khỏi liên doanh, trở thành doanh nghiệp 100\% vốn nước ngoài.

Những năm gần đây, sức cạnh tranh trong thu hút FDI của nước ta đang có dấu hiệu giảm sút rõ rệt. Ví dụ điển hình như: Nhật, dù vẫn là nhà đầu tư số 1 tại $\mathrm{VN}$, nhưng đang đầu tư hàng tỷ USD vào Myanmar, quốc gia đang thu hút sự chú ý của cả thế giới. Toyota, Mitsubishi và nhiều tập đoàn lớn khác của Nhật đã tuyên bố mở rộng cơ sở sản xuất tại Thái Lan, Malaysia, nhưng các cơ sở của họ ở VN vẫn án binh bất động. Nhật có tới hơn 7.000 doanh nghiệp ở Thái Lan nhưng mới có 1.500 doanh nghiệp ở $\mathrm{VN} \ldots$

Những tồn tại, hạn chế nêu trên của khu vực FDI có nguyên nhân từ sự yếu kém nội tại của nền kinh tế cũng như những hạn chế trong việc hoạch định và thực thi chính sách, pháp luật về đầu tư nước ngoài.
Các nguyên nhân chủ yếu là:

- Hệ thống, pháp luật chính sách liên quan đến đầu tư chưa đồng bộ và thiếu nhất quán.

- Chính sách ưu đãi đầu tư chưa đủ sức hấp dẫn.

- Sự phát triển của cơ sở hạ tầng chưa đáp ứng được nhu cầu phát triển của nền kinh tế cũng như chưa tạo điều kiện tốt để dòng vốn ĐTNN phát huy hiệu quả.

- Hạn chế về nguồn nhân lực.

- Sự phát triển của các ngành công nghiệp phụ trợ còn hạn chế.

- Chưa thực hiện tốt công tác phân cấp quản lý ĐTNN.

- Công tác kiểm tra, giám sát về việc thực hiện các quy định về bảo về môi trường của các doanh nghiệp còn nhiều bất cập.

- Công tác xúc tiến đầu tư chưa hiệu quả.

Thực trạng này tiếp tục đặt ra cho $\mathrm{VN}$ những bài toán lớn từ vấn đề luật pháp, chính sách, quy hoạch lãnh thổ, ngành nghề, cơ sở hạ tầng, nguồn nhân lực, công tác giải phóng mặt bằng, phân cấp trong quản lý FDI, môi trường, v.v. để khai thác lợi thế cũng như hạn chế những tác động tiêu cực của FDI khi VN ngày càng hội nhập sâu rộng hơn vào nền kinh tế thế giới.

\section{Một số biện pháp khuyến nghị góp phân nâng cao chất lượng dòng vốn FDI}

Thứ nhất, cải cách thủ tục hành chính, tạo điều kiện thuận lợi nhất cho các nhà đầu tư nước ngoài đầu tư vào VN. Tại Hội nghị Báo cáo tổng kết 25 năm đầu tư trực tiếp nước ngoài, Thủ tướng Nguyễn Tấn Dũng cũng nhấn mạnh, cải cách chính sách, thủ tục hành chính là động lực 
thúc đẩy dòng vốn ngoài. Thủ tướng chỉ đạo các Bộ trưởng nhanh chóng cải cách chính sách, thủ tục hành chính cho doanh nghiệp FDI, chấm dứt tình trạng 2-3 năm mới duyệt xong một dự án.

Thứ hai, cần rà soát lại một cách đồng bộ để đổi mới, giảm thiểu tác động xấu của thể chế, môi trường kinh tế vĩ mô, cơ sở hạ tầng, giáo dục và đào tạo... nâng cao năng lực cạnh tranh của nền kinh tế. Theo Đề án "Đánh giá thực trạng FDI và định hướng đến năm 2020" được Bộ Kế hoạch và Đầu tư soạn thảo, trước mắt cần lựa chọn một số giải pháp trong các nhóm liên quan đến FDI đã được đề xuất trong đề án để tổ chức thực hiện một cách triệt để. Trước hết là xây dựng chiến lược FDI nằm trong tổng thể phát triển kinh tế - xã hội VN giai đoạn 2011-2020 và trong tổng thể chính sách tăng cường năng lực cạnh tranh, nâng cao năng suất và kết nối với các chính sách/chiến lược khác. Tiếp đến là xây dựng quy hoạch gọi vốn FDI theo ngành, vùng lãnh thổ để qua đó thấy rõ được những lĩnh vực, ngành nghề, dự án, địa bàn cần và có thể liên doanh, cho phép nước ngoài thực hiện. Đối với những lĩnh vực, ngành nghề mà $\mathrm{DN}$ trong nước đầu tư và kinh doanh có chất lượng, chi phí so sánh được với dự án FDI thì ưu tiên cho khu vực trong nước. Kế đến là việc hoàn thiện thể chế, mà trước hết về tổ chức bộ máy, vì thực tế hiện nay công tác quán lý nhà nước đối với FDI đang phân cấp cho các địa phương thực hiện một số chức năng quản lý nhà nước và thiếu một cơ quan quản lý nhà nước có đủ thẩm quyền để điều phối hoạt động nói trên. Tiếp tục hoàn thiện hệ thống pháp lý liên quan đến đầu tư mà trước hết là khắc phục các chồng chéo, mâu thuẫn trong quy định của Luật Đầu tư và các luật khác như về cơ quan đăng ký kinh doanh và cơ quan cấp giấy chứng nhận đầu tư, về chuyển nhượng dự án đầu tư và chuyển nhượng cổ phần, về tuân thủ điều kiện đầu tư trong góp vốn, mua cổ phần giữa Luật Doanh nghiệp, Luật Đầu tư; về đối tượng được hưởng ưu đãi đầu tư quy định tại Luật Đầu tư và Luật Thuế thu nhập DN; về sự không thống nhất về lĩnh vực và địa bàn ưu đãi đầu tư giữa Luật Đầu tư với các Luật Thuế thu nhập DN, Luật Thuế xuất nhập khẩu.

Thú $\boldsymbol{b} \boldsymbol{a}$, cải thiện môi trường đầu tư và nâng cao năng lực cạnh tranh của môi trường đầu tư $\mathrm{VN}$ là một yêu cầu cấp thiết đối với công tác quản lý nhà nước về FDI, đòi hỏi được thực hiện liên tục không chỉ hiện nay mà cả các giai đoạn phát triển sau này của đất nước. Cần có chiến lược, có định hướng, có quy hoạch, có một bộ máy đủ mạnh về quản lý FDI để xác định các bước đi dài hạn nhằm đạt tới mục tiêu đặt ra, tuy vậy chúng ta đều rõ các vấn đề về chiến lược, quy hoạch, tổ chức lại bộ máy, nhất là vấn đề nhân sự cho bộ máy... là những vấn đề tổng hợp, phức tạp không thể hoàn thành trong ngắn hạn một năm. Khi thực hiện các bước đi dài hạn đó cần tổ chức thực hiện ngay các tác nghiệp nhỏ trong các bước đi ngắn hạn hàng năm.

Thú $\boldsymbol{t} u$, coi trọng và tăng cường công tác đào tạo nhằm nâng cao chất lượng nguồn nhân lực đáp ứng yêu cầu của các doanh nghiệp nói chung và doanh nghiệp FDI nói riêng; triển khai thành lập bộ phận xúc tiến đầu tư tại một số địa bàn trọng điểm; xây dựng quy chế phối hợp chặt chẽ giữa các cơ quan xúc tiến đầu tư, xúc tiến thương mại các cấp.

\section{Kết luận}

Thuyết "Cái vòng luẩn quẩn" và "Cú huých từ bên ngoài" của Samuelson có ý nghĩa quan trọng nhất là đối với các nước đang phát triển như VN. Lý thuyết đã đưa ra nền tảng cơ sở lý thuyết cho việc vận dụng các yếu tố để đạt mục tiêu tăng trưởng nền kinh tế, trong đó yếu tố vốn đầu tư trực tiếp nước ngoài được nhiều quốc gia sử dụng. Tuy nhiên các quốc gia nhất là $\mathrm{VN}$ khi sử dụng nguồn vốn đầu tư từ nước ngoài như một "cú huých" để tăng trưởng nền kinh tế cần thận trọng và cân nhắc để đạt hiệu quả sử dụng yếu tố này là cao nhất

\section{TÀI LIẸU THAM KHẢO}

Bộ Kế hoạch và Đầu tư. Đề án “Đánh giá thực trạng FDI và định hướng đến năm 2020".

Nguyễn Thị Cành, Trần Hùng Sơn. (2009). Vai trò của đầu tư trực tiếp nước ngoài đối với phát triển và tăng trưởng kinh tế ở VN. Tạp chí Phát triển Kinh tế (225)

Phạm Minh Chính và Vương Quân Hoàng. (2009). Kinh tế VN - Thăng trầm và đột phá. NXB Chính trị quốc gia.

Mai Ngọc Cường. (2005). Lịch sủ các học thuyết kinh tế. NXB Lý luận chính trị

Trần Nguyễn Trọng Xuân. (2006). Đầu tu trục tiếp nước ngoài với công cuộc công nghiệp hóa, hiện đại hóa ở VN. NXB Khoa học xã hội. Hà Nội.

Võ Thanh Thu \& Ngô Thị Ngọc Huyền. (2008). Kỹ thuật đầu tu trục tiếp nuoớc ngoài, NXB Thống kê. 


\section{TÀI LIỆU THAM KHẢO}

Bộ Kế hoạch và Đầu tư. (2016). Đề án "Đánh giá thực trạng FDI và định hướng đến năm 2020".

Nguyễn Thị Cành, Trần Hùng Sơn. (2009). Vai trò của đầu tư trực tiếp nước ngoài đối với phát triển và tăng trưởng kinh tế ở VN. Tạp chí Phát triển Kinh tế (225).

Phạm Minh Chính, Vương Quân Hoàng. (2009). Kinh tế Việt Nam: Thăng trầm và đột phá. NXB Chính trị quốc gia, Hà Nội.

Mai Ngọc Cường. (2005). Lịch sử các học thuyết kinh tế. NXB Lý luận chính trị, Hà Nội.

Trần Nguyễn Trọng Xuân. (2006). Đầu tư trực tiếp nước ngoài với công cuộc công nghiệp hóa, hiện đại hóa ở VN. NXB Khoa học xã hội. Hà Nội.

Võ Thanh Thu, Ngô Thị Ngọc Huyền. (2008). Kỹ thuật đầu tư trực tiếp nước ngoài. NXB Thống kê. 